\title{
Zoványi Nikolett': A büntetőjogi és a polgári jogi felelősség jogkövetkezményeinek összevetése
}

Debreceni Jogi Műhely, 2012. évi (IX. évfolyam) 4. szám (2012. október) 47-60.

\section{A felelősségről általában}

A felelősség, mint elvont és elméleti kategória egyes források szerint Franciaországban ${ }^{2}$ politikai fogalomként született meg valamikor a XVIII. század második felében. ${ }^{3}$ Schipani és mások későbbi kutatásai azonban igazolták, hogy a felelősség, mint fönév az olasz és az angol politikai nyelvezetben már a XVIII. század derekán megjelent. Nem vitatható el azonban a franciáktól, hogy a Napóleon uralkodása alatt elkészült Code civile-ben már jogi fogalomként használták a felelősség kifejezést, és a kódex hatására más nyelvekben és jogi kultúrákban is hamar elterjedt.

A kifejezés hosszú fejlődésen ment keresztül, aminek következtében egy sokrétü, több értelemben is használt, kissé parttalan fogalommá vált. ${ }^{4}$

A felelösség általános értelemben a társadalmi normáknak való állandó alávetettséget jelenti, valamint jelentéstartalmába beletartozik a társadalmi normák megsértése esetére elöírt szankcióknak való alávetettség. Felelősségről azonban nem csak társadalmi értelemben beszélhetünk. A társadalmi felelősségtől megkülönböztethető a jogi felelősség (jogi normáknak való alávetettség) és a nem jogi felelősségek, úgy, mint a politikai, az erkölcsi, stb. felelösségek.

Jogi felelősség tovább bontható egyrészt büntetőjogi, másrészt polgári jogi felelősségre, ahol a polgári jogi felelősség szintén differenciálható. Két fajtája a kontraktuális (szerződés megszegéséért való felelősség) és deliktuális (szerződésen kívül okozott károkért fennálló felelősség) felelősség.

„A felelősséget - Eörsi Gyula szavaival élve - társadalmi értelemben valamely felróhatóan elkövetett társadalomra veszélyes magatartás váltja ki. A felelősség a társadalom nevelö funkciójának az a része, amely represszióval reagál a társadalomra veszélyes magatartásokra." A társadalomra veszélyes magatartásokat az állam jogellenessé nyilvánítja, és kikényszeríthető szankciókkal sújtja azokat, ezáltal védekezve a veszélyes magatartásokkal szemben a jog eszközeinek segítségével, kialakítva a jogi felelősség szabályait.

\section{A büntetőjogi és a polgári jogi felelősség szétválása}

A kezdetektől máig hosszú fejlődésen ment keresztül a büncselekmények áldozatainak helyzetének megítélése, kárpótlása. Kezdetben a magán- és vérbosszú idején nem kizárólag az állam gyakorolta a büntetöhatalmat, hanem a sértett, vagy családja, nemzetsége. E büntetőhatalom részben fizikai erőszak alkalmazását, részben vagyoni váltságot jelentett. A politikai hatalom azonban igyekezett saját kezébe összpontosítani az eddig tradíciókon alapuló igazságszolgáltatást, s azt az állam igényeinek megfelelően alakítani. A hagyományos nemzetségi igazságszolgáltatás átalakult, az állam büntetőhatalmát képviselö bírák szerepe és hatalma megerösödött. ${ }^{6}$

A sértett fél vagy családjának, közösségének vagyoni, és ezáltal magánjogi jellegü kompenzálása az elszenvedett sérelmekért, fájdalmakért már hamar megjelent a történelemben, felváltva a kezdeti magán- és vérbosszú intézményeit. A kompozíció, a megváltás magánjogi jellegü szankció, mely meghatározó jelentőségü lépés volt az állami büntetőhatalom és az állami normák által szabályozott büntetőjog kialakulása tekintetében. ${ }^{7}$ Alkalmazására általában a magánszemély élete és testi épsége elleni büncselekmények esetén került sor. A kompozíciót a sértő fél és a sértett, illetve a közössége közötti alku alakította ki. 
A kompozíció lényegében egy lehetőséget jelentett az olyan büncselekmények esetében, amelyeknél a jogsértés az élet, testi épség és egészség jogi tárgyak ellen irányult. Ráadásul ezekben az esetekben a cselekmény bosszú formájában való megtorlása gyakran végződött az elkövető életének elvételével. A megváltás - bár erősen diszkriminatív formában alternatívát jelentett a legsúlyosabb magánbüntetés kiváltására az okozott sérelem következményeinek csillapítását szolgáló pénzösszeg fizetésével vagy más dolog átadásával. ${ }^{8}$ A kompozíció elterjedésével a büntetőjog a közjogiasodás szakaszába lépett, ami magával hozta a sértett szerepkörének gyengülését. Ez a folyamat vezetett oda, hogy fokozatosan kiteljesedett azon büncselekmények száma, melyeket hivatalból üldöztek az arra hivatott állami szervek, míg a magánbüncselekmények száma visszaszorult. Végül az állam teljes mértékben monopolizálta, magának vindikálta a büntetőhatalmat. A közjogi jelleg felöltése innentől alapvetően elkülönítette a büntetőjogot a magánjogi jellegü polgári jogtól. A büntetőjog ugyanis a büncselekményekkel szembeni védekezésben felismerte az állami és közösségi érdeket, és a kompozícióból kinövően megszülte a polgári jogi felelősség és a büntetőjogi felelősség különbözőségét. Ennek következtében többé nem a büntetőjog területéhez tartozott azoknak a károknak a megtérítése, melyet a büncselekmény elkövetője a sértettnek okozott, hanem a polgári jog területére került. ${ }^{9}$ A büntetőjog köréből a sértett akaratának jelentősége fokozatosan kikopott, és a polgári jogi kártérítés keretei közé vándorolt át.

A polgári jog és a büntetőjog felelösség fogalmai között, valamint a jogi felelősség e két területéhez kapcsolható szankciók és más joghatások, jogkövetkezmények meghatározásának tekintetében évszázadok óta jól körülhatárolható, éles választóvonal létezik. A jogellenesnek nyilvánított magatartások megvalósítják valamely, az egyes nemzeti alkotmányokban és nemzetközi egyezményekben foglalt alapjog vagy a közbiztonság sérelmét mind a polgári, mind a büntetőjogban. A jogsértésekre adott válaszok és reakciók irányultsága azonban más funkcionális tartalommal bír a büntetőjog és a polgári jog körében. A büntetőjog központi elemét a speciális és generális prevenció jelenti, míg néhány jogrendszerben megjelenik a retorzió is. A polgári jog szintén magán viseli a prevenció jegyeit, azonban a személyi és vagyoni sérelmek körében általános szankcióként a kártérítés helyezkedik el, ami pedig a reparációt, illetve erkölcsi és más sérelmek bekövetkezése esetén a kompenzációt juttatja érvényre. Megállapítható azonban a két jogterület együttes hatását vizsgálva egymást kiegészítő jellegük, mely által komplex védelmet képesek megvalósítani. A két jogterület komplementer jellege az Alaptörvényben deklarált jogok garanciáit hivatott teljes egészében megvalósítani. ${ }^{10}$

A tanulmány célja annak bemutatása, hogy hogyan kapcsolódott mégis össze a polgári jogi kártérítés és a büntetőjogi kárjóvátétel jogintézménye, mely jellemzők differenciálják őket, illetve melyek mutatják közös eredetüket.

\section{A magyar rendszer A Csemegi-kódex}

Az első írott büntető törvénykönyv Magyarországon a Csemegi-kódex volt ${ }^{11}$, mely már tartalmazott rendelkezéseket a sértett kárainak megtérítésére, azonban ezeket az igényeket kártérítés címszó alatt tárgyalta. A szóhasználat azonban nem volt teljesen a véletlen müve, hanem a jogalkotó logikus gondolkozásának eredménye. Az indokok között megtalálható az, hogy ekkor még nem létezett egységes, írott magánjogi törvénykönyv és a miniszteri indoklás ${ }^{12}$ szerint a gyakorlat ennek következtében bizonytalan volt; elismerte a jogalkotó azt, hogy egy büncselekmény elkövetése után keletkezhetnek olyan kárigények, melyeket nem lehet érvényesíteni egy polgári peres eljárás keretei között. Ezeket az indokokat alátámasztotta a később megszülető bünvádi perrendtartásról szóló törvény ${ }^{13}$, amely bevezette 
az ún. adhéziós eljárást, mely alapján egy eljárásban elbírálhatóvá vált büntető- és polgári jogi igény. ${ }^{14}$

Az elkövetett büncselekmény alapján kérelemre vagy hivatalból ítélt meg kártérítést a büntető bíróság. Abban az esetben, ha a sértett túlélte az ellene elkövetett büncselekményt - ilyen volt például a testi sértés esete -, csak akkor ítélt meg kártérítést a büntetöügyben eljáró bíróság, ha a sértett azt igényelte. Amennyiben megítélt kártérítést a bíróság, az összeg megállapítása során figyelembe vette a sértett büncselekményt követő állapotát ${ }^{15}$, személyi és családi körülményeit ${ }^{16}$, és ezek alapján még azt is mérlegelhette a bíróság, hogy a kártérítés összegét egyösszegben vagy évi járadék formájában állapítsa meg. ${ }^{17}$ Ezzel szemben, ha emberölés vagy gyilkosság vádjával folyt eljárás, akkor az elhunyt sértett olyan hozzátartozóinak, akiket a sértett eltartott, hivatalból ítélt meg kártérítést a bíróság. ${ }^{18} \mathrm{~A}$ bíróság határozott ez esetben is abban a kérdésben, hogy a kártérítést egyösszegben vagy évi járadékként kell megfizetnie az elítéltnek.

A Csemegi-kódexben tehát kétséget kizáróan magánjogi jogkövetkezményeket szabályoztak a sértett kárainak megtérítésére, amit nem polgári bíróság előtt folyó polgári peres eljárásban lehetett csak megállapítani, hanem már a büntetőeljárás alatt elbírálták. A Csemegi-kódexben szabályozott kártérítés, illetve a 119. §-ban pénzbüntetésnek nevezett jogkövetkezmény magánjogi természetét az alábbi tényezők igazolják:

> Amennyiben az elítélt személy királyi kegyelemben részesült, a kiszabott kártérítés összeget akkor is meg kellett térítenie, vagyis a pénzbüntetés vagy kártérítés elengedésére nem terjedt ki a királyi kegyelem hatálya. ${ }^{19}$

> Érvényesült a kérelemhez kötöttség elve, vagyis a büntetőbíróság csak akkor ítélt meg kártérítési összeget, ha azt a sértett külön kérte keresetében. E szabály alól egy kivétel létezett, ugyanis ha a sértett életét vesztette az ellene irányult támadás következtében, a hozzátartozók részére az ő külön kérelmük nélkül, hivatalból állapított meg kártérítést a bíróság. ${ }^{20}$

> Végrehajtása nem hivatalból, hanem kérelemre, a vonatkozó magánjogi szabályok szerint történt. ${ }^{21}$

$>$ Amennyiben többen közösen követték el a büncselekményt, úgy egyetemlegesen voltak kötelezhetők a kár megtérítésére ${ }^{22}$, vagyis a sértett bármelyik elkövetőtől követelhette a kártérítés összegének megfizetését, illetve amennyiben valamelyik elkövető megtérítette az összeget, úgy valamennyien szabadultak a kárkötelemböl. Amely elkövető megfizette a teljes összeget, a többi elkövetővel szemben léphetett fel megtérítési igénnyel.

> A kártérítési kötelezettség teljesítésére és elévülésére nem a büntetőjogi szabályokat, hanem a polgári jogi elévülés intézményének szabályait kellett alkalmazni. ${ }^{23}$

> Végül a megítélt kártérítési kötelezettség magánjogi természetét támasztja alá az a tény is, hogy a jogerős ítéletben megállapított összeg az örökösök által örökölhető volt $^{24}$, a hagyatékhoz tartozott. Amennyiben a sértett nem tudta azt behajtani időközben bekövetkezett halála miatt, úgy az örökösei felléphettek az elkövetővel szemben a jogerősen megítélt kártérítési összeg állami eszközökkel történő végrehajtása útján.

Mindezeken túl meg kell még jegyezni azt, hogy a Csemegi-kódex miniszteri indoklása külön is magánjog természetünek nevezi a Csemegi-kódexben szabályozott kártérítést, és a 119. §ban pénzbüntetésnek nevezett jogintézményt is.

A Csemegi-kódex kártérítésre vonatkozó szabályait több büntetőjogász is bírálta. Problémát jelentett az, hogy például nem a kódex általános részében került rögzítésre az okozott károk megtérítésére vonatkozó kártérítési kötelezettség, hanem csupán a kódexben szabályozott egyes büncselekményeknél. A probléma forrását tehát az adta egyrészről, hogy bár bizonyos bűncselekmények jogkövetkezményei között szerepelt a kártérítési kötelezettség, a kódex 
bőven tartalmazott még olyan vétségeket és büncselekményeket, ahol szükséges lett volna az okozott károk megtérítését rendezni. ${ }^{25}$ Véleményem szerint ezeknél a büntetteknél is lehetősége volt a sértettnek kárai megtérítését követelni, azonban nem érvényesíthette igényét a büncselekményt elbíráló büntetőeljárás során, hanem külön polgári peres eljárást kellett kezdeményeznie. Az adhéziós eljárás tehát csak szük körben volt alkalmazható a Csemegikódex alapján.

A bírálatok másik gócpontját a büncselekményi kör megítélése jelenti. A kódex gyilkosság és emberölés, valamint testi sértés esetén elöírt kártérítési kötelezettséget, de nem rendelkezett arról, hogy mi a helyzet halált okozó testi sértés esetén, amikor a sértett nem tudta maga igényelni a kárainak megtérítését, de nem is minősül szándékos vagy gondatlan emberölésnek. Nem volt egyértelmü a kódex szóhasználata például kívánságra ölés, magzatelhajtás, öngyilkosságra rábírás esetén.

Véleményem szerint mindenképpen elörehaladó szemléletet jelent az adhéziós eljárás megengedésének lehetősége, azonban a Fayer László által képviselt kritikát valóban megalapozottnak tartom: amennyiben bizonyos büncselekmények esetén megengedhetőnek vélte a jogalkotó az adhéziós eljárás lefolytatását, és ezáltal az elkövetőnek a bűncselekménnyel okozott károk megtérítésére kötelezését már a büntetőeljárás során, akkor azt minden olyan büncselekményre alkalmazni kellett volna, ahol a sértettnek valamilyen kára is keletkezett az elkövetö cselekménye következtében.

Mindenképpen meg kell még jegyeznünk azt is a Csemegi-kódex szabályai kapcsán, hogy léteztek a kárjóvátételnek speciális esetei. Az az elkövető, aki visszalépett cselekményétől, vagy a már megkezdett cselekmény következtében beálló károkat még azok tényleges beállta előtt elhárította, a büntetőjogi felelősségre vonás során büntetlenséget élvezhetett. ${ }^{26}$

\section{A hatályos magyar szabályozás}

A bűncselekmények áldozatainak járó kárenyhítésről először a 209/2001. (X. 31.) kormányrendelet rendelkezett. Célja elsődlegesen az volt, hogy az áldozatoknak azonnali és gyors pénzügyi segítséget nyújtson, amennyiben a büncselekményt követően erre rászorultak. A téma törvényi szintü szabályozására 2005-ben került sor, amikor az országgyülés elfogadta a büncselekmények áldozatainak segítéséről és az állami kárenyhítésről szóló 2005. évi CXXXV. törvényt, mely 2006. január 1-jén lépett hatályba. A törvény sajátossága, hogy áldozat-fogalma a korábbi szabályozástól tágabb kört ölelt fel, és a kárenyhítés -bár marad a központi elem - kiegészül más áldozatsegítő szolgáltatásokkal. Ezek között találunk olyan eszközöket, amelyek a vagyoni károkat igyekeznek kompenzálni, ${ }^{27}$ míg mások az áldozat jogainak egyszerübb, gyorsabb érvényesítéséhez nyújtanak segítséget. ${ }^{28}$ Mivel Magyarország 2004. május 1-je óta tagja az Európai Uniónak, így a szabályozás már az Európa Tanács által e területre megfogalmazott alapelvek tükrében történt, az Unióban létező kárenyhítési irányzatok közül a kockázat elosztó biztosítási konstrukciót alkalmazva.

A jogosulti kör meghatározásánál a fő szempont a bűncselekmény eredménye. Az eredmény alapján áldozatnak minősül az a személy, aki a büncselekmény közvetlen következményeként sérelmet szenved el. Bár a büntetőjogi kárenyhítés rokonítható, összekapcsolható a polgári jogi kártérítés, különösen a nem vagyoni kártérítés intézményével, lényeges különbség, hogy az áldozatok kárenyhítéséről rendelkező törvény konkrétan meghatározza, hogy mit ért lelki sérülés, érzelmi megrázkódtatás alatt. A polgári jogban a nem vagyoni kártérítésnél nem találunk ilyen mankót az igazságszolgáltatás számára, hanem a bíróság vizsgálja az eseteket. Büntetőjogi szempontból így a lelki sérülés megalapozottságához és bizonyításához elegendő az áldozatban kialakult tartós, komoly félelem, szorongás; az érzelmi megrázkódtatás bizonyításához az áldozat pszichés zavara, traumája, mely a büncselekményt követően alakult ki benne. A polgári jogi kártérítés és a büntetőjogi jóvátétel között ez egy logikus és 
jogpolitikailag is alátámasztható különbséget eredményez, hiszen az állami kárenyhítés célja, hogy már a büntetőeljárás alatt, jogerős ítélet bevárása nélkül meghatározott mértékig kompenzálja az áldozatot.

Magyarország a kárenyhítésre jogosító körülmények között három feltételt vizsgál, melyek az elkövető szándéka, cselekményének társadalomra veszélyességének foka és a büncselekmény eredménye. Ezek alapján hármas kör részesülhet kárenyhítésben: az a személy, aki ellen szándékos, személy elleni, eröszakos büncselekményt követtek el (sértett); az ő közeli hozzátartozója; valamint azok a személyek, akiket a sértett eltart. Ezen a ponton ismét találunk egy különbséget a polgári jogi nem vagyoni kártérítés és a büntetőjogi kompenzáció között, hiszen nem vagyoni kártérítésnél létezett a súlyos és tartós jelzö, amit az Alkotmánybíróság alkotmányellenesnek nyilvánított ${ }^{29}$, míg a büntetőjogi kárenyhítésnél jogszerüen kívánja meg az állam, hogy a testi épség vagy az egészség károsodása, mint a büncselekmény eredménye bekövetkezzen.

Míg az előző különbségek a büntetőjogi és a polgári jogi intézmények kezelése között nem vitatott, addig az áldozat visszatérítési kötelezettségére megállapított 3 éves ${ }^{30}$ periódus nehezen igazolható. A polgári jog szabályai szerint ugyanis 5 év van a vagyoni és nem vagyoni károk érvényesítésére, míg a büncselekmények áldozatainak segítéséről szóló törvény alapján 3 éven belül követelheti vissza az állam az áldozattól a kárenyhítésként az áldozat rendelkezésére bocsátott azon összeget, amely más forrásból megtérült. Amennyiben tehát 3 és 5 év között térül csak meg az áldozat oldalán keletkezett vagyoni és nem vagyoni kár, vagy a végrehajtás miatt még tovább elhúzódik az elkövető tényleges teljesítése, úgy a jelenleg hatályos szabályok alapján az állam már nem élhet visszatérítési igényével.

Összességében megállapítható a törvényröl, hogy az európai garanciákat betartva megfelelő támogatást biztosít a büncselekmények áldozatainak, mind pénzügyi, mind pedig információs, segítségnyújtásra irányuló szolgáltatásaival.

\section{Nemzetközi szervezetek törekvései}

A XIX. század közepe-vége elött a büntetőeljárásoknak nem az volt az elsődleges célja, hogy az áldozat valamilyen formában jóvátételt nyerjen az elszenvedett büncselekmény következtében őt ért károkért, szenvedésekért, hanem az állami büntetőhatalom érvényesítése, az elkövető megbüntetése, ezáltal elrettentő példa statuálása. Amennyiben az elkövetőt pénzbüntetéssel (is) sújtották, a befolyt összeg az államot illette meg, nem a sértettet, az áldozatot.

A XIX. század vége felé alakult ki a viktimológia tudománya, mely kifejezetten az áldozatok helyzetére, az áldozattá válás megelőzésére, a bűncselekmény során az áldozatokat ért károk enyhítésére és jóvátételére helyezte a hangsúlyt.

Azonban már az irányzat kialakulása előtt voltak, akik hangsúlyozták az áldozatokat ért vagyoni és pszichés hátrányok, megrázkódtatások enyhítésének fontosságát. Egy francia jogtudós, Bonneville de Marsengy már 1847-ben megjelent müvében felvetette azt, hogy az áldozatoknak az állam jutasson jóvátételt egy külön erre a célra létrehozott állami kártalanítási alapból, amely a biztosítási rendszerek mintájára müködne. ${ }^{31}$ A téma fontosságát az 1889-ben megalakult Nemzetközi Büntetőjogi Egyesület, valamint az 1924-ben létrehozott Nemzetközi Büntetőjogi Társaság is hangsúlyozta. A Nemzetközi Büntetőjogi Egyesület megalakulását követően évente tartott kongresszusain kiemelt témaként kezelte az áldozatok helyzetével kapcsolatosan, hogy az áldozatokat ért kár megtérült-e, kompenzálásra került-e. Vizsgálódásaik eredményeképpen 1891-ben végül egy határozat formájában is megfogalmazták konklúzióikat. Ebben a dokumentumban elégtelennek nyilvánították azokat a válaszokat, amelyek a sértettek reparációs, kompenzációs igényeire érkeznek. Álláspontjuk alapján a modern büntetőjog még mindig nem veszi kellően figyelembe a sértetteknek ezen 
irányú igényeit. Napvilágot láttak azok az elképzelést is, miszerint ha az elítélt nem rendelkezik elég vagyonnal ahhoz, hogy jóvátegye az okozott kárt, akkor rabkeresményéböl kell azt megtérítenie. ${ }^{32}$ Határozatukban megfogalmazták azon irányú törekvésüket, hogy amennyiben az elkövető a kárt meghatározott időn belül megtéríti, és kisebb súlyú vagyoni büncselekményről van szó, akkor biztosítson ez mentesülést az elkövetőnek, kivéve, ha visszaesőként már követett el vagyon elleni büncselekményt. ${ }^{33}$

A kártalanítási programok közül a legjelentősebb elgondolás Margary Fry nevéhez köthető. Elképzelései alapján az áldozatoknak fizetendő kárjóvátétel, kártérítés alapja nem az, amit az elítéltek a szabadságvesztés büntetésük alatt rabmunkájukkal megkeresnek. Véleménye szerint e célra létre kellene hozni egy olyan állami alapot, amely nem a biztosítások, veszélyközösségek mintájára müködik, hanem fenntartása az állam kötelezettsége lenne, ezáltal közfeladatnak minősülne.

A téma fontosságát bizonyítja, hogy már a nemzetközi börtönügyi konferenciákon is foglalkoztak ez idő tájt az elkövető jóvátételi, kártérítési kötelezettségének és az állam általi kártalanítás, kárjóvátétel kérdéseivel. Többek mellet a neves büntetőjogtudós, Prins szintén síkra szállt annak érdekében, hogy a büncselekmények áldozatai kompenzációban részesülhessenek.

A folyamat kiteljesedését a Budapesten megrendezett Nemzetközi Büntetőjogi Társaság XI. Kongresszusa $^{34}$ jelentette, ahol a harmadik témakör „A büncselekmények áldozatainak kompenzációja" címen került meghirdetésre. A témakör három főbb pont köré szerveződött, így az állami kártalanítási alap közpénzekből történő létrehozásának kérdése; a sértett számára egyszerüsítést nyújtó egységes adhéziós eljárások lefolytatásának lehetősége, valamint egyéb olyan intézkedések számbavétele és szabályainak kidolgozása, amely a sértett kompenzálását célozza.

A kongresszus által meghozott határozatban rögzítették azon büncselekmények körét, ahol mindenképpen elvárás az állammal szemben, hogy kárpótolja az áldozatokat. Ezek azok az élet és testi épség, mint elkövetési tárgy ellen irányuló bűncselekmények, amelyeket szándékosan követtek el. ${ }^{35}$ A határozat személyi hatályát tekintve igen tágan határozza meg azoknak a személyeknek a körét, akik kompenzálásra jogosultak. Ide tartoznak a sértetten kívül a sértett tartásra jogosult hozzátartozói, valamint azok a külföldi állampolgárok, akik ellen adott állam területén követtek el büncselekményt. ${ }^{36}$

A kongresszus eredményeként említhető, hogy bár már annak lebonyolítása előtt is kialakultak nemzeti rendszerek, amelyek állami segítséget, kompenzálást nyújtottak a büncselekmények áldozatainak, a konferencián lehetősége nyílt a nemzetközi büntető jogászoknak, hogy ezeket a rendszereket és általuk elért eredményeket elemezzék, és példaként állítsák más országok elé. Ezt követően az 1970-es évek végére Nyugat-Európa más államaiban is elterjedt az állami kártalanítási rendszereknek, alapoknak a létrehozása. ${ }^{37}$

A konferencia komolyságát és a megfogalmazott tételek kimagasló színvonalú kidolgozottságát mutatja az, hogy olyan elvárások láttak napvilágot, melyek az Európai Unió célkitűzéseit és a tagállamok számára előírt jogharmonizációs kötelezettséget a mai napig is lefedik.

\section{Az Európai Unió jogharmonizációs tevékenysége}

Az Európa Tanács 1975-ben felállított egy bizottságot, melynek feladata, hogy egységes elveket dolgozzon ki az áldozatok kárpótlására. Az 1977-ben elfogadott elvek azonban nem rendelkeztek kötőerővel, így a gyakorlatban nem érvényesültek. Az Európa Tanácsban végül 1983-ban elfogadták European Convention on the Compensation of Victims of Violent Crimes címet viselő európai egyezményt. Ez az egyezmény már kötelezettségeket rótt a tagállamokra a jóvátétel formájának és a szervezetrendszernek az alapelveit rögzítve. Az egyezmény 
elhatárolja egymástól a büntetőjogi és a polgári jogi kompenzációt, azok célja és egymáshoz való viszonya alapján. A büntetőjogi kompenzáció a büncselekmény tényéből következik, és csupán gyorssegélyt és kárenyhítést jelent az áldozatoknak, viszont kizárólag olyan károkra vonatkozik, amelyek más forrásból nem vagy nem teljes mértékben térülnek meg. A polgári jogi kompenzációtól abban is különbözik ez a gyorssegélyt jelentő szubszidiárius jogintézmény, hogy az áldozat már a büntető ítélet kihirdetése és jogerössé válása előtt hozzáférhet a kompenzációs összeghez. A káronszerzés tilalma polgári jogi elv kiküszöbölését - amelynek itt is érvényesülnie kell - azzal biztosítja az egyezmény, hogy az állam megkapja a lehetőséget a gyorssegély folyósítása előtt vagy után, hogy levonja vagy visszatérítést követeljen az áldozatnak más forrásból megtérülö kompenzációhoz, kártérítéshez.

Az egyezmény külön hangsúlyt helyez a tájékoztatásra, melynek során a kérelmezőket információkkal látják el az őket megillető jogokról, az eljárás lefolytatásáról, segítséget nyújtanak az áldozatok számára formailag és tartalmilag helyes keresetlevél benyújtásában. $\mathrm{Az}$ egyezmény legnagyobb pozitívumaként azonban az értékelendő, hogy olyan minimumszabályokat határoz meg, melyeknek minden körülmények között érvényesülniük kell.

2004 óta az egyezményen kívül európai irányelv is rendelkezik az áldozatok kompenzálásáról Európai Unió 2004/80/EK irányelve ${ }^{38}$ keretében. ${ }^{39}$ Bár az irányelv kötelezően előírja az állam által az áldozatoknak nyújtandó kárenyhítést is, ez mégis csak másodlagos szerepet tölt be. Az irányelv elsődleges célkitüzése, hogy megteremtsen egy olyan rendszert, amely tartalmazza a bünelkövető által elkövetett cselekmény jóvátételének formáit, valamint ezeknek a büntetőjogi értékelését.

A téma szempontjából szintén lényeges a 2001/220/IB sz. kerethatározat, mely többek között előírja az Európai Unió tagállamai bíróságainak, hogy a büntetőeljárás keretein belül, ésszerü határidők betartása mellett olyan határozatot hozzanak, amely a kiterjed az elkövető által a sértett, az áldozat részére fizetendő kompenzációra is. ${ }^{40} \mathrm{Az}$ adhéziós eljárások fontosságát és alkalmazásának kívánatosságát emeli ki a kerethatározat, mely alapján a büncselekmény sértettjének nem kell külön bíróság előtt külön eljárásban érvényesítenie az őt ért vagyoni és nem vagyoni károkat, hanem azt az ügyben eljáró büntető bíróság is megítélheti.

\section{Az áldozat kompenzálásának egyes formái: kártalanítás, kártérítés, kárjóvátétel, kárpótlás}

A középkor kezdetéig egy bűncselekmény sértettjének a kárpótlása, bosszújának kielégítése jelentette az elkövető megbüntetésének fö formáját. Az állami büntetőhatalom kialakulásával és közjogivá válásával azonban az áldozatok jogai, szerepe, az érdekeinek minél hangsúlyosabban történő figyelembe vétele háttérbe szorult, s helyébe az állam lépett. A XIX. század közepétől azonban ismét kezdett elötérbe kerülni az áldozatok helyzete, majd létrejött egy kizárólag az áldozatokra koncentráló büntetőjogi irányzat, a viktimológia.

A viktimológia irányzatát képviselő jogtudósok érdeklődésének egyik központi eleme az áldozatok kárpótlásának kérdése, a büncselekménnyel okozott károk és hátrányok helyrehozása, jóvátétele. A szakirodalom általában a kártalanítás szót használja ez ilyen irányú követelések megjelölésére, ${ }^{41}$ ami nem biztos, hogy helyt álló elnevezés a kártalanítás jogintézményének polgári jogi technikus terminusát ismerve. A következő fejezetben kísérletet teszek arra, hogy az egyes jogintézmények között különbségeket, a hozzájuk tartozó jelentéstartalmat feltárva elkülönítsem azokat.

A fogalmak tisztázása kapcsán először azt kell leszögeznünk, hogy két féle jóvátétele létezik egy büncselekménynek, melyek fö elhatárolási pontja a kárt megtérítő személy kiléte. Az egyik esetben ugyanis maga a bünelkövető az, aki megtéríti az általa okozott kárt, míg a 
másik esetben az állam áll helyt az elkövető helyett, ha az valamilyen oknál fogva nem képes elégtétel nyújtani a sértettnek. Ez a különbségtétel azonban az áldozat szempontjából tulajdonképpen lényegtelen, hiszen számára a legfontosabb mozzanat, hogy kára megtérítésre kerüljön, mindegy ki fizeti azt meg. A kár megtérítésének formájáról azonban már nem mondható el, hogy teljesen lényegtelen. Ezért szükséges dogmatikailag vizsgálni az egyes megtérítési formák közötti különbséget.

Kártalanításra kötelezésre ezzel szemben akkor kerülhet sor, ha a cselekvő magatartása nem volt jogellenes, mert arra jogszabály kifejezetten engedélyt adott, vagy szükséghelyzetben cselekedett a kárt okozó személy. ${ }^{42}$ Eörsi úgy véli, hogy ,a magatartást okozata: a kár avatja jogellenessé". ${ }^{43}$ A szakirodalomban azonban a legtöbben a kártalanítást nem felelősségi formának tekintik, mivel nem történik normaszegés. ${ }^{44,45}$ Valamely jogszabály ad engedélyt bizonyos magatartás kifejtésére, mely adott esetben másoknak kárt okozhat. Mivel nincs jogellenes cselekmény, így normaszegésként nem értelmezhetö, így nem követelhető kártérítés.

Kártérítési felelősség fennállása esetén a fentiekkel szemben a jog (a Ptk.) vélelmezi a magatartás jogellenességét. A károkozó tudja bizonyítani azt, hogy magatartása jogszerü volt, de ha nem sikerül ezt a tényt bizonyítania, akkor helyt kell állnia az okozott kárért a kártérítési felelősség szabályai alapján, vagyis a teljes kárt meg kell térítenie.

A fenti megállapításból következik, hogy a kártalanítás és a kártérítés különbözik a tekintetben is, hogy a kártérítési felelősség a teljes kár megtérítésének elvén alapul. Kártérítés esetén elsődleges az in integrum restitutio, az eredeti állapot helyreállítása. Ez alapján a kárt okozó személynek olyan helyzetbe kell hoznia a károsult felet, mintha a kár be sem következett volna. Amennyiben nincs lehetőség az eredeti állapot helyreállítására, vagy azt a károsult valamely okból nem kívánja, úgy az okozott kár pénzben történő megtérítésére, vagyoni kártérítésre kell kötelezni a károkozót. A keletkezett vagyoni kár három elemből tevődik össze, a ténylegesen felmerült kárból (damnum emergens), az elmaradt haszonból (lucrum cessans), valamint az indokolt költségekböl. Kártérítés nemcsak a vagyonban bekövetkezett értékcsökkenés esetén követelhető, hanem a személyiségi jogok megsértése esetén is. A nem vagyoni károk megtérítése körében nem lehet a keletkezett hátrányt a vagyoni kár elemeire bontani, nehezen értelmezhető a teljes kártérítés alapelve. A személy személyiségi jogaiban keletkezett hátrányt kell ilyen esetben kompenzálni.

A büntetőjogi kompenzációnak a kártérítéssel összevetve nem feladata az eredeti állapot helyreállítása, az áldozatnak okozott valamennyi kár maradéktalan megtérítése, ami a kártérítés egyik alapelvét jelenti. Az e témában született 1983-as európai egyezmény is úgy fogja fel a kompenzációt, mint az áldozat kárainak enyhítésére szolgáló gyorssegélyt. Ezért is nevezhetjük ezt a „segélyt” jóvátételnek, kárenyhítésnek, kompenzációnak, de semmiképpen sem kártérítésnek, kártalanításnak. A kárenyhítésként megállapítható összegekről pedig tudva lévő, hogy a büncselekmények áldozatainak segítéséről szóló törvényben megtalálható klasszifikáción alapulnak, így elöre kiszámíthatóak. Ez is igazolja, hogy itt sem a nem vagyoni, sem a vagyoni károk nem kerülnek megtérítésre és figyelembe vételre, hiszen ez ténylegesen csak az áldozatok számára egy gyors segítségként szolgál.

Vagyoni kártérítésnél nem kizárólag a teljes kártérítés elve érvényesül, hanem a káron szerzés tilalmának is érvényre kell jutnia. A káronszerzés tilalmának elve kimondja, hogy a károsult nem hozható előnyösebb helyzetbe a károkozás miatt, mint amiben a kár bekövetkezése elött volt. Nem kell tehát a kárnak azt a részét megtérítenie a károkozónak, amely a károsult felróható magatartásának a következményeként állott elő. Ezekkel a megállapításokkal szemben kártalanításnál a károsult oldalán beállott valamennyi kárt nem feltétlenül fogja fedezi a kártalanítási összeg. A káronszerzés tilalma a büntetőjogi jóvátétel esetén is érvényesül, ezért írja elő az európai egyezmény is, hogy amennyiben a sértett a jóvátételen kívül azt megelőzően vagy annak rendelkezésére bocsátását követően bármilyen más 
forrásból kártérítéshez, kompenzációhoz jut, akkor az állam annak összegéből levonhatja a jóvátétel összegét, vagy kérheti, hogy térítse azt vissza részére a sértett. ${ }^{46}$

További szempont, hogy vagyoni károk megtérítése körében a bíróság méltányossági jogkörében eljárva - figyelemmel a károkozó helyzetére - mérsékelheti a bekövetkezett és a bírósági eljárás során érvényesíteni kívánt károk megtérítésére vonatkozó kötelezettség mértékét, vagyis csökkenthető a kártérítés összege. Kártalanítás esetén nincs lehetösége a bíróságnak méltányossági vagy más okból beleavatkoznia a megtérítési jogviszonyba, nem csökkentheti a törvény, jogszabály által jogszerüvé tett, ezáltal megengedett cselekvés következményeként fellépő károk kártalanítás formájában történő megtérítésére vonatkozó kötelezettség teljesítése körében megállapított összeget. Kárpótlás, jóvátétel esetén az 1983-as európai egyezmény eleve meghatározott egy alsó és egy felső küszöbértéket a részes államok számára, mely alatt illetve felett nem kell enyhíteni a sértett kárát. Ezen túl az egyezmény a személyi kör alapján is erősen behatárolja, hogy mikor lehet és kell az államnak jóvátételt fizetni az áldozatnak. Ez abban nyilvánul meg, hogy a sértett anyagi helyzetét figyelembe veszik, és csak azoknál terheli ilyen kötelezettség az államot, akik szerényebb anyagi körülmények között élnek, nem tudják más forrásból megtéríteni az őket ért károkat, és az állami jóvátételre rászorulnak.

Megállapítható, hogy míg a kártérítés föként az elszenvedett károk miatti helyzet kiküszöbölésére, az eredeti állapot helyreállítására törekszik - ezáltal elsődleges funkciója a helyreállítás, reparáció -, addig a kártalanítás valamely eshetőlegesen bekövetkező hátránytól kíván megóvni. ${ }^{47} \mathrm{Az}$ állam általi jóvátétel pedig a keletkezett károk azonnali enyhítésre szolgál.

Kártalanítás esetén soha nem jár a károk megtérítése automatikusan, azt külön igényelni kell a jogszerüen cselekvő, mégis kárt, hátrányt okozóval szemben. Nem is feltétlenül biztos, hogy jár kártalanítás a jogszerüen elszenvedett károk helyreállítása végett. Ezzel szemben amennyiben valaki egy másik személynek kárt okoz, köteles azt megtéríteni. A kártérítés automatikusan jár, kivéve, ha a károkozónak sikerül bizonyítania, hogy szubjektív felelösség esetén úgy járt el, ahogy az az adott helyzetben általában elvárható, vagy objektív kártérítési felelősség fennállása esetén a külön jogszabályban meghatározott mentesülési okok valamelyikét tudja bizonyítani a károkozó, s így sikerül mentesülnie az okozott hátrány megtérítésének kötelezettsége alól. Az állam általi jóvátétel nem jár automatikusan, hanem az a büncselekményi körtől függ, és az áldozatnak az eljárás alatt jeleznie kell ez irányú kérelmét.

A kártalanítás a jogszerüen okozott károk jóvátételére használt eszköz. A károk bekövetkezése jogszerü magatartás következménye, nincs jogellenesség. Mentesülésre nincs lehetőség, hiszen eleve csak akkor kell kártalanítás formájában megtéríteni az okozott kárt vagy annak egy részét, ha valamely jogszabály azt külön elöírja. Ilyen szempontból a kártalanítás egy objektív helytállási kötelezettséget testesít meg, hiszen jogszabályi kötelezettség esetén sem meghatározott okból, sem méltányosságból nincs helye az exculpatiónak. Az állam általi jóvátétel, kárenyhítés esetén nincs helye kimentésnek, hiszen taxatíve meg van határozva, hogy mely büncselekmények elkövetése esetén mely sértetti körnek jár.

Az ENSZ egyik munkaokmánya ${ }^{48}$ és az Európa Tanács dokumentumai ${ }^{49}$ szintén a „,restitution” és a „,compensation” megjelölést alkalmazzák, mely kifejezések a jóvátétel és a kártérítés megfelelői a magyar terminológiában. Az ENSZ okmány 8. és 12. pontjaiban rendelkezik egyrészt arról, hogy ,az elkövetőknek és harmadik személyeknek - amennyiben lehetőségük engedi - tisztességes jóvátételt kell fizetniük a magatartásuk miatt az áldozatnak, családjának és hozzátartozóinak”, ${ }^{50}$ másrészt „ha az elkövetőtől vagy más forrásból nem térül meg teljesen a kár, az államnak erőfeszítéseket kell tennie, hogy pénzügyi kárpótlást biztosítson” 51 bizonyos esetekben. Az Európa Tanács „Az áldozat helyzete a büntető anyagi 
jog és eljárásjogban" címü ajánlásában elöírja a tagállamoknak, hogy az áldozatot - többek között - tájékoztatni kell azon lehetőségéröl, hogy jóvátételt és kártérítést, kárpótlást kérjen az elkövetőtől. ${ }^{52}$ A bíróság számára kötelezettségként elöírja azt is, hogy mielőtt ítéletet hoznak, minden olyan információval rendelkeznie kell, amely a sértett által elszenvedett sérülésekre és kárra vonatkozik, különösen az áldozat igényeit a kárpótlásra nézve, valamint, hogy az elkövető fizetett-e már bármilyen jóvátételt, kárpótlást, vagy tett-e valamilyen őszinte erőfeszítést evégből. ${ }^{53}$

\section{Záró gondolatok}

Sajnálatos módon a büntető jogirodalomban elterjedt az a nézet, hogy a „compensation” szót helytelenül kártalanításként fordítják. Ellentétben az angolszász jogrendszerekkel, melyek nem tesznek különbséget kártalanítás és kártérítés jogintézmények között, a magyar jogrendszer igen. Az eredeti angol szövegek helytelen fordítása pedig folyamatos félreértésekhez, félreértelmezésekhez vezetett és vezethet. Nyilvánvaló, hogy a magyar büntetőjog is képes arra, hogy különbséget tegyen kártalanítás és kártérítés között, méghozzá a polgári jogban használt fogalmakkal operálva. Gondolok itt például a jogtalan fogvatartás és kényszerintézkedések alkalmazására azokkal a vádlottakkal szemben, akiknek bünössége végül nem nyert bizonyítást. A büntetőeljárásról szóló törvény 3. címében rendelkezik a kártalanításról olyan esetben, amikor a terhelttel szemben kényszerintézkedést foganatosítottak, azonban a büntetőeljárás jogerős lezárása során mégsem állapították meg a bünösséget. ${ }^{54} \mathrm{Az} 582$. § külön rendelkezik arról, hogy a kártalanítás módjára és mértékére a Polgári Törvénykönyvnek a szerződésen kívül okozott kárért való felelősségére vonatkozó rendelkezéseit a büntetőeljárásról szóló törvényben foglalt eltérésekkel kell alkalmazni. ${ }^{55}$

Az állam általi jóvátétel, kompenzáció, mely egy erre a célra létrehozott közalapból történik, véleményem szerint helytelenül viseli a kártalanítás elnevezést, hiszen az áldozatok szemszögéből vizsgálva a történteket mindenképpen egy jogellenes cselekményt követtek el ellenük. Az állam sem jogellenes, sem jogszerü cselekményt nem követett el, nem ő okozta a sértett kárát, de nincs más, aki megtéríthetné a kárt, vagy az elkövető nem képes azt megtéríteni, így az áldozat kompenzálását az állam vállalja magára. ${ }^{56} \mathrm{Az}$ államot így kártérítési kötelezettség terheli, vagyis ezekben az esetekben csupán kártelepítésről beszélhetünk.

Az elkövető által az áldozatnak fizetett összeget már valóban helyes lehet jóvátételek nevezni, hiszen itt a kártérítés egy olyan speciális formájáról van szó, ahol az elkövető nem csupán a károsult vagyona vagy személyiségi jogai ellen követ el valamilyen jogellenes cselekményt, hanem olyan tettet követ el a sértettel szemben, amelynek a polgári jogi jogkövetkezményeken túl büntetőjogi relevanciái is vannak.

Véleményem szerint mindenképpen kívánatos lenne a büntetőjogi és polgári jogi felelősség jogkövetkezményeinél egyforma jelentéstartalommal megtölteni az azonos elnevezésü jogintézményeket, különös tekintettel arra, hogy a külföldi szakirodalom is a „restitution” és a „,compensation” kifejezéseket alkalmazza ezekben az esetekben. Álláspontom alapján a probléma abban gyökerezik, hogy a fordítók - általában jogászi végzettség nélkül - a „,compensation” szót kártalanításként és kártérítésként egyaránt fordítják, mely helytelen.

\section{Felhasznált irodalom}

1. AszTALOS László: Szankció és felelősség a polgári jogban, In: Felelősség és szankció a jogban, KJK, Budapest, 1980.

2. BARABÁS Andrea Tünde: Kárjóvátétel a magyar büntető igazságszolgáltatás történetében, Magyar Jog, 1993/11. sz., 649-653. 
3. BERKES György: A büntetőjogi felelösség feltételei, Büntetőjogi kodifikáció, 2002/3. sZ., 25-28.

4. BLASKÓ Béla: Mozzanatok az európai büntetőjog fejlödésének történetéböl a feudalizmus virágzó és felbomló szakaszában, Collectio Iuridica Universitatis Debreceniensis, 2006/6. sz., 51-75.

5. BLASKÓ Béla: A büntetőjogi felelösség filozófiai alapjáról, Jogtudományi közlöny, 1995/2. sz., 90-93.

6. EÖRSI Gyula: A jogi felelösség alapproblémái, Akadémia Kiadó, Budapest, 1961.

7. EÖRSI Gyula: Kötelmi jog. Általános rész. Nemzeti Tankönyvkiadó, Budapest, 2003.

8. FAYER László: A magyar büntetöjog kézikönyve, Franklin-Társulat, Budapest, 1900.

9. FARKAS Ákos: Kárjóvátétel és büntetöjog avagy hogyan kapcsolódhat egymáshoz elmélet és jogalkotás, Magyar Jog, 1994/7. sz., 443-444.

10. FÉZER Tamás: A büncselekmények áldozatainak járó jóvátétel elméleti kérdései”, Debreceni Jogi Műhely, VIII. évfolyam 3. szám, 2011. július

11. FÉzer Tamás: A polgári jogi felelösség természete, In: Fézer Tamás szerk. A kártérítési jog magyarázata, Complex Kiadó, Budapest, 2010.

12. FÉZER Tamás: Lehet-e büntetni a magánjog eszközeivel? Gondolatok a sérelemdíj funkciójáról, In: Merre tart a magyar civilisztikai jogalkotás a XXI. század elején?, Kódex, Pécs, 2010.

13. FINKEY Ferencz: A magyar büntetöjog tankönyve, Grill Károly Könyvkiadó vállalata, Budapest, 1914.

14. FöLDI András: A jogi felelősség fogalmáról, Acta Facultatis Politico-Iuridicae Universitatis Scientiarium Budapestinensis De Rolando Eötvös Nominatae, Tomus XXX., 1988. 10.

15. FöLDI András - HAMZA Gábor, A római jog története és institúciói, Nemzeti Tankönyvkiadó, Budapest, 1996.

16. GÖRGÉNYI Ilona: A büncselekmények áldozatainak okozott kár jóvátétele, Jogtudományi Közlöny, 1993/6. sz., 231-241.

17. GÖRGÉNYI Ilona: Kárjóvátétel a büntetöjogban, mediáció büntetöügyekben, Budapest, Hvg-Orac, 2006.

18. GÖRGÉNYI Ilona: Some issues of the compensation and restitution for crime victims, Acta Juridica Hungarica : Hungarian Journal of Legal Studies, 1994/1-2. sz., 105-111.

19. GYÖRGYI Kálmán: XI. Nemzetközi Büntetőjogi Kongresszus, Budapest, 1974. szeptember, Jogtudományi Közlöny, 1975/1. sz.

20. IsAÁK Gyula: A büntettekről és vétségekröl szóló Büntetö Törvénykönyv (1878. évi V. törvénycikk) és a büntetteket és vétségeket megállapitó újabb törvényes rendelkezések, Grill Károly Könyvkiadó vállalata, Budapest, 1926.

21. KAUTZ Gusztáv: A magyar büntetöjog tankönyve, Különös tekintettel a gyakorlati élet igényeire. Eggenberger-féle Könyvkereskedés, Budapest, 1881.

22. KENDERES Andrea: A büntetö kártérités múltja, jelene és jövöje, Polgári Jogi Kodifikáció, 2008/5-6. sz., 36-42.

23. LÁBADY Tamás: Az eszmei és büntető kártérités a common law-ban, Állam- és Jogtudomány, 1994/1-2. sz., 69-112.

24. LÁZÁR Miklós: A büntetőjogi felelösség tágitásának útvesztői, Jogtudományi közlöny, 1988/8. sz., 472-475.

25. Löw Tobiás (szerk.): Csemegi-kódex. A magyar büntetötörvénykönyv a büntettekröl és vétségekröl (1878. évi 5. törvénycikk) és teljes anyaggyüjteménye, Második kötet, Budapest, 1880.

26. MADAI Sándor: A csalás büntetőjogi értékelése, Budapest, Hvg-Orac, 2011. 
27. MolnÁR Imre: Magánjogi, illetve büntetőjogi felelösség az ókori Rómában Marton Géza tanitása szerint, Acta Universitatis Szegediensis: Acta juridica et politica, 2009. (72. Tom.)1-22. Fasc., 357-362.

28. MoLNÁR Imre: Magánjogi és büntetőjogi felelösség találkozási pontjai az ókori római jogban, Acta Universitatis Szegediensis: Acta juridica et politica, 2007. (69. Tom.) 148. Fasc., 511-536.

29. PETRIK Ferenc: Kártéritési jog, Az élet, testi épség. egészség megsértésével szerzödésen kívül okozott károk megtéritése, HVG-Orac Kiadó, Budapest, 2002.

30. Stephen SCHAFER: Restitution to Victims of Crime, London-Chicago, 1960.

31. Stephen SCHAFER: The Victim and his Criminal. A study in functional responsibility, New York, 1968.

32. SchMitz, Stefan: Nélkülözhetetlen fogyasztóvédelem vagy túlzott mértékü kártérités? Kártérités az USA-ban, Magyar jog, 2000/2. sz., 94-99.

33. TREMMEL Flórián: A magánvád, Közgazdasági és Jogi Könyvkiadó, Budapest, 1985.

Jogszabályok:

1. 1878. évi V. törvénycikk

2. 1896. évi XXXIII. törvénycikk

3. 1998. évi XIX. törvény a büntetőeljárásról

4. 34/1992. AB határozat

5. 2005. évi CXXXV. törvény

6. Council of Europe: The Position of the Victim in the Framework of Criminal Law and Procedure, 28 June 1985.

7. Declaration of Basic Principles of Justice for Victims of Crime and Abuse of Power, Adopted by General Assembly resolution 40/34 of 29 November 1985.

8. Council Framework Decision of 15 March 2001 in the standing of victims in criminal proceedings, 2001/220/JHA

9. Council Directive 2004/80/EC of relating to compensation to crime victims

\section{A tanulmány a TÁMOP-4.2.2./B-10/1-2010-0024 számú pályázat keretében jelent meg.}

\footnotetext{
${ }^{1}$ III. éves, nappali tagozatos PhD hallgató, DE Marton Géza Állam- és Jogtudományi Doktori Iskola

2 FöLDI András: A jogi felelősség fogalmáról, Acta Facultatis Politico-Iuridicae Universitatis Scientiarium Budapestinensis De Rolando Eötvös Nominatae, Tomus XXX., 1988. 10.

${ }^{3}$ A responsabilité kifejezést használták a felelősség fogalmára.

${ }^{4}$ FölDI András - HAMZA Gábor, A római jog története és institúciói, Nemzeti Tankönyvkiadó, Budapest, 1996. , 424.

${ }^{5}$ EÖRSI Gyula: Kötelmi jog. Általános rész. Nemzeti Tankönyvkiadó, Budapest, 2003., 239.

${ }^{6}$ GÖRGÉNYI Ilona: Kárjóvátétel a büntetőjogban, mediáció a büntetöügyekben, Budapest, Hvg-Orac, $2006 ., 9$.

${ }^{7}$ GÖRGÉNYI Ilona: Kárjóvátétel a büntetőjogban, mediáció a büntetőügyekben, Budapest, Hvg-Orac, $2006 ., 9$.

${ }^{8}$ FÉZER Tamás: A büncselekmények áldozatainak járó jóvátétel elméleti kérdései”, Debreceni Jogi Műhely, VIII. évfolyam 3. szám, 2011. július

9 Lásd erről bővebben: BARABÁs Andrea Tünde: Kárjóvátétel a magyar büntető igazságszolgáltatás történetében, Magyar Jog, 1993/11. sz., 649-653.

${ }^{10}$ FÉZER Tamás: A büncselekmények áldozatainak járó jóvátétel elméleti kérdései”, Debreceni Jogi Műhely, VIII. évfolyam 3. szám, 2011. július

11 1878. évi V. törvénycikk.

${ }^{12}$ Csemegi-kódex. A magyar büntetőtörvénykönyv a büntettekröl és vétségekről (1878. évi 5. törvénycikk) és teljes anyaggyüjteménye, második kötet, Löw Tobiás (szerk.), Budapest, 1880., 503.

13 1896. évi XXXIII. törvénycikk.
} 
${ }^{14}$ Ezt a megoldás már az 1872. évi ideiglenes bűnvádi eljárási törvényjavaslat is tartalmazta 111. §-ában. Lásd erről bővebben: TREMMEL Flórián: A magánvád, Közgazdasági és Jogi Könyvkiadó, Budapest, 1985.

${ }^{15}$ Kialakult-e például tartós betegség vagy munkaképtelenné vált-e a sértett.

${ }^{16}$ Szegény vagy tehetősebb; hozzátartozóit eltartja-e. 1878. évi V. törvénycikk, 128. §.

${ }^{17} 1878$. évi V. törvénycikk, 311. §.

${ }^{18} 1878$. évi V. törvénycikk, 292. §.

${ }^{19}$ KAUTZ Gusztáv: A magyar büntetőjog tankönyve, Különös tekintettel a gyakorlati élet igényeire. Eggenbergerféle Könyvkereskedés, Budapest, 1881., 336.

${ }^{20}$ 1878. évi V. törvénycikk, 292. §, lásd erröl még: FINKEY Ferencz: A magyar büntetőjog tankönyve, Grill Károly Könyvkiadó vállalata, Budapest, 1914.

${ }^{21}$ Lásd 9. lábjegyzet.

${ }^{22}$ Lásd 9. lábjegyzet.

${ }^{23}$ IsAÁK Gyula: A büntettekről és vétségekről szóló Büntető Törvénykönyv (1878. évi V. törvénycikk) és a büntetteket és vétségeket megállapitó újabb törvényes rendelkezések, Grill Károly Könyvkiadó vállalata, Budapest, 1926., 182.

${ }^{24}$ Lásd erröl: FAYER László: A magyar büntetőjog kézikönyve, Franklin-Társulat, Budapest, 1900., illetve FINKEY Ferencz: A magyar büntetöjog tankönyve, Grill Károly Könyvkiadó vállalata, Budapest, 1914.

${ }^{25}$ A problémát többek között Fayer László bírálta. Lásd bővebben: FAYER László: A magyar büntetőjog kézikönyve, Franklin-Társulat, Budapest, 1900.

26 1878. évi V. törvénycikk, 67. §, 225. §, 240. §, 427. §277. §. Lásd erröl bővebben: GöRGÉNYI Ilona: Kárjóvátétel a büntetőjogban, mediáció a büntetöügyekben, Budapest, Hvg-Orac, 2006., 14-18.

${ }^{27}$ A büntetőjogban a vagyoni kár fogalmáról, elemiről, valamint a kár fogalmához kapcsolódó egyes elméletekről lásd bővebben: MADAI Sándor: A csalás büntetöjogi értékelése, Budapest, Hvg-Orac, 2011., 129149.

${ }^{28}$ Utóbbi áldozatsegitő eszköz nem képezi a tanulmány szerves részét, ezért arról bővebben lásd: FézER Tamás: A büncselekmények áldozatainak járó jóvátétel elméleti kérdései”, Debreceni Jogi Mühely, VIII. évfolyam 3. szám, 2011. július

${ }^{29} 34 / 1992$. AB határozat

${ }^{30}$ 2005. évi CXXXV. törvény: 15 . § (1) bekezdése

${ }^{31}$ Bővebben lásd: Stephen SCHAFER: The Victim and his Criminal. A study in functional responsibility, New York, 1968.

${ }^{32}$ Lásd bővebben: Stephen SCHAFER: Restitution to Victims of Crime, London-Chicago, 1960.

${ }^{33}$ GÖRGÉNYI Ilona: Kárjóvátétel a büntetőjogban, mediáció a büntetőügyekben, Budapest, Hvg-Orac, 2006., 19.

${ }^{34}$ Nemzetközi Büntetőjogi Kongresszus, Budapest, 1974. szeptember 9-15.

${ }^{35}$ Hangsúlyozandó, hogy ezek csupán a kongresszuson jelen lévő büntetö jogtudósoknak a minimum elvárásai, ettől többet bármelyik állam vállalhatna egy megvalósuló szabályozás esetén.

${ }^{36}$ GYÖRGYI Kálmán: XI. Nemzetközi Büntetőjogi Kongresszus, Budapest, 1974. szeptember, Jogtudományi Közlöny, 1975/1. sz., 59.

${ }^{37}$ Új-zéland 1963., brit 1964., észak-ír 1968.

${ }^{38}$ Council Directive 2004/80/EC of relating to compensation to crime victims

39 Elözményt jelentő 1983. évi európai egyezmény (European Convention on the Compensation of Victims of Violent Crimes) a halált, a súlyos testi sértést okozó, valamint az egészségkárosodást okozó szándékosan elkövetett büncselekmények esetén elöírta az állam kötelező kártalanítási kötelezettségét. Az Irányelv alapján tágabb kör részesülhet állami kártalanításban, hiszen az a szándékosan elkövetett, erőszakos cselekmények áldozatait illeti meg.

40 Council Framework Decision of 15 March 2001 in the standing of victims in criminal proceedings, 2001/220/JHA, Article 9. Lásd bővebben: GöRGÉNYI Ilona: Kárjóvátétel a büntetőjogban, mediáció a büntetöügyekben, Budapest, Hvg-Orac, 2006.

${ }^{41}$ GÖRGÉNYI Ilona: A büncselekmények áldozatainak okozott kár jóvátétele, Jogtudományi Közlöny, 1993/6. sz., 231.

42 Jogellenességet kizáró tényező a károsult beleegyezése és a jogos védelmi helyzet, azonban ezekben az esetekben nem kell sem kártérítést, sem kártalanítást fizetnie a kár okozójának.

${ }^{43}$ EÖRSI Gyula: A jogi felelösség alapproblémái, Akadémia Kiadó, Budapest, 1961., 294.

${ }^{44}$ Lásd: FÉzer Tamás: A polgári jogi felelösség természete, In: Fézer Tamás szerk. A kártérítési jog magyarázata, Complex Kiadó, Budapest, 2010., AszTAlos László: Szankció és felelösség a polgári jogban, In: Felelősség és szankció a jogban, KJK, Budapest, 1980., 277.

${ }^{45}$ Vannak azonban olyan álláspontok,amik amellett érvelnek, hogy a felróhatóság hiánya nem változtatja meg a a minősítését a jogkövetkezménynek, így a kártalanítás esetén is megvan az a dogmatikai alap, ami a felelösség 
szintjére emeli azt. Lásd bővebben: PETRIK Ferenc: Kártéritési jog, Az élet, testi épség. egészség megsértésével szerzödésen kívül okozott károk megtéritése, HVG-Orac Kiadó, Budapest, 2002., 284.-290.

${ }^{46}$ Az Egyezmény 9. cikke: With a view to avoiding double compensation, the State or the competent authority may deduct from the compensation awarded or reclaim from the person compensated any amount of money received, in consequence of the injury or death, from the offender, social security or insurance, or coming from any other source.

${ }^{47}$ FÉZER Tamás: A polgári jogi felelősség természete, In: Fézer Tamás szerk. A kártérítési jog magyarázata, Complex Kiadó, Budapest, 2010., 29.

${ }^{48}$ Declaration of Basic Principles of Justice for Victims of Crime and Abuse of Power, Adopted by General Assembly resolution 40/34 of 29 November 1985.

${ }^{49}$ Council of Europe: The Position of the Victim in the Framework of Criminal Law and Procedure, 28 June 1985.

${ }^{50}$ Declaration of Basic Principles of Justice for Victims of Crime and Abuse of Power, Adopted by General Assembly resolution 40/34 of 29 November 1985., 8. pont: „Offenders or third parties responsible for their behaviour should, where appropriate, make fair restitution to victims, their families or dependants. Such restitution should include the return of property or payment for the harm or loss suffered, reimbursement of expenses incurred as a result of the victimization, the provision of services and the restoration of rights."

${ }^{51}$ Declaration of Basic Principles of Justice for Victims of Crime and Abuse of Power, Adopted by General Assembly resolution 40/34 of 29 November 1985., 12. pont: When compensation is not fully available from the offender or other sources, States should endeavour to provide financial compensation to:

(a) Victims who have sustained significant bodily injury or impairment of physical or mental health as a result of serious crimes;

(b) The family, in particular dependants of persons who have died or become physically or mentally incapacitated as a result of such victimization.

${ }^{52}$ Council of Europe: The Position of the Victim in the Framework of Criminal Law and Procedure, 28 June 1985., I./D/9. pont: The victim should be informed of:

- the date and place of a hearing concerning an offence which caused him suffering;

- his opportunities of obtaining restitution and compensation within the criminal justice

process, legal assistance and advice;

- how he can find out the outcome of the case.

${ }^{53}$ Council of Europe: The Position of the Victim in the Framework of Criminal Law and Procedure, 28 June 1985., I./D/12. pont: All relevant information concerning the injuries and losses suffered by the victim should be made available to the court in order that it may, when deciding upon the form and the quantum

of the sentence, take into account:

- the victim's need for compensation;

- any compensation or restitution made by the offender or any genuine effort to that end.

54 1998. évi XIX. törvény a büntetőeljárásról, 580-584. §§

55 1998. évi XIX. törvény a büntetőeljárásról, 582. §

${ }^{56} \mathrm{Az}$ állam kompenzációs kötelezettségének alapjairól lásd például: FÉZER Tamás: A büncselekmények áldozatainak járó jóvátétel elméleti kérdései”, Debreceni Jogi Mủhely, VIII. évfolyam 3. szám, 2011. július 